\title{
Second generation of fucose-based DC-SIGN ligands : affinity improvement and specificity versus Langerin $\uparrow$
}

\author{
Manuel Andreini, $\uparrow^{a}$ Daniela Doknic, $\uparrow^{a}$ Ieva Sutkeviciute, $\uparrow^{b, e}$ José J. Reina, ${ }^{a}$ Janxin Duan, ${ }^{c}$ Eric Chabrol, ${ }^{b, e}$ \\ Michel Thepaut, ${ }^{b, e, f}$ Elisabetta Moroni, ${ }^{a}$ Fabio Doro, ${ }^{a}$ Laura Belvisi, ${ }^{a}$ Joerg Weiser, ${ }^{c}$ Javier Rojo, ${ }^{d}$ \\ Franck Fieschi ${ }^{* b, e, g}$ and Anna Bernardi ${ }^{* a}$
}

Received 11th April 2011, Accepted 20th May 2011

DOI: 10.1039/c1ob05573a

DC-SIGN and Langerin are two C-type lectins involved in the initial steps of HIV infections: the former acts as a viral attachment factor and facilitates viral invasion of the immune system, the latter has a protective effect. Potential antiviral compounds targeted against DC-SIGN were synthesized using a common fucosylamide anchor. Their DC-SIGN affinity was tested by SPR and found to be similar to that of the natural ligand Lewis-X $\left(\mathrm{Le}^{\mathrm{X}}\right)$. The compounds were also found to be selective for DC-SIGN and to interact only weakly with Langerin. These molecules are potentially useful

therapeutic tools against sexually transmitted HIV infection.

\section{Introduction}

Dendritic Cells (DCs) are instrumental in the development of pathogen-specific immune responses. ${ }^{1}$ DCs are professional antigen-presenting cells that capture microbes entering skin or mucosal tissues and process them to form MHC-peptide complexes. After antigen uptake, immature DCs acquire the capacity to migrate to lymph nodes where they present processed antigens to T-cells, initiating adaptive immune responses. DCs express a repertoire of pathogen-recognition receptors (PRRs), including Toll Like Receptors (TLRs) and C-type lectins that mediate both signaling by self antigens and, in some cases, pathogen recognition. ${ }^{2}$ C-type lectins represent a large family of $\mathrm{Ca}^{2+}$ dependent lectins and recognize pathogen-derived carbohydrate structures. Many different C-type lectins expressed by DCs have been described, ${ }^{3}$ including DC-SIGN.

DC-SIGN (DC-Specific ICAM-3 Grabbing Nonintegrin; CD 209) was originally defined as an intercellular adhesion molecule-3

'Universita' degli Studi di Milano, Dipartimento di Chimica Organica e Industriale and CISI, via Venezian 21, 20133 Milano, Italy. E-mail: anna. bernardi@unimi.it

${ }^{b}$ Institut de Biologie Structurale, Université Grenoble I, 41 rue Jules Horowitz, 38027 Grenoble, France. E-mail: fieschi@ibs.fr

'Anterio consult\&research, Augustaanlage 23, D-68165 Mannheim

${ }^{d}$ Glycosystems Laboratory, Instituto de Investigaciones Quimicas, CSICUniversidad de Sevilla, Américo Vespucio 49, 41092 Sevilla, Spain

${ }^{\circ} \mathrm{CNRS}$, UMR 5075, Grenoble, France

${ }^{f} C E A$, Grenoble, France

${ }^{g}$ Institut Universitaire de France, 103 boulevard Saint-Michel, 75005 Paris, France

$\dagger$ Electronic supplementary information (ESI) available: . See DOI: $10.1039 /$ clob05573a

\$ These authors, listed in alphabetical order, contributed equally to this work
(ICAM-3) receptor that plays an important role in establishing the first contact between DC and resting T cells. ${ }^{4} \mathrm{It}$ is a type II transmembrane C-type lectin with a single C-terminal Carbohydrate Recognition Domain (CRD) within its sequence. In the cellular membrane, DC-SIGN is assembled as a tetramer, thanks to an extended coiled-coil region that allows simultaneous presentation of four CRDs. ${ }^{5}$ This oligomerization influences the lectin avidity in binding events. DC-SIGN appears to promote dissemination of a number of viruses (e.g., HIV, hepatitis C virus, Ebola virus $)^{6}$ and to participate in suppressing immune responses to some pathogens, (e.g., Mycobacterium tuberculosis and Helicobacter pylori). ${ }^{7}$

The various roles attributed to DC-SIGN have generated much interest towards the identification of ligands that can be used to explore its different functions and/or to inhibit pathogen binding. ${ }^{8}$ However, generation of specific ligands for DC-SIGN is a challenging task, since many other C-type lectins exist and share important structural features with DC-SIGN binding site. Among the list of C-type lectin receptors closely related to DCSIGN, Langerin, which is also expressed at the cell surface of antigen presenting cells, and L-SIGN, expressed on endothelial liver cell, placenta and lymph nodes, are particularly likely to interfere with DC-SIGN recognition. ${ }^{9,10}$ These three lectins are all calcium-dependent carbohydrate-binding proteins and share the ability to bind high-mannose oligosaccharides. On the other hand, the three lectins show different specificity towards fucosylated oligosaccharides, a fact which may be used to design DC-SIGN specific ligands. Indeed, contrary to L-SIGN, DC-SIGN is known to bind the Lewis $\mathrm{X}\left(\mathrm{Le}^{\mathrm{X}}\right)$ epitope (Galß4[Fuc $\left.\alpha 3\right] \mathrm{GlcNAc}, 1$ in Fig. 1), as illustrated in the recognition mode of Schistosoma mansoni egg by these lectins. ${ }^{5 \mathrm{~d}, 7,11}$ Moreover, both DC-SIGN and Langerin appear to recognize blood group B antigen through its fucose residue ${ }^{12,13}$ in the primary $\mathrm{Ca}^{2+}$ binding site, but again the $\mathrm{Le}^{\mathrm{X}}$ antigen is specific for DC-SIGN relative to Langerin. As 


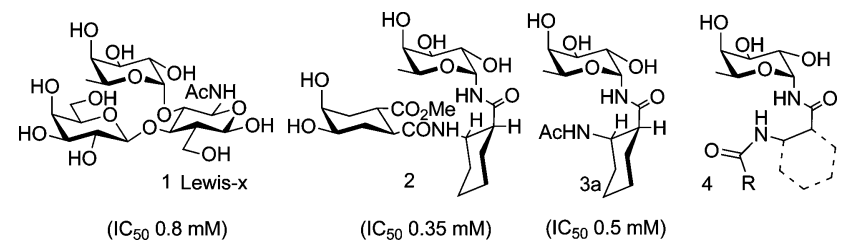

Fig. 1 The known fucose-based DC-SIGN ligands 1-3a and the general structure 4 of the library described in this paper. $\left(\mathrm{IC}_{50}\right.$ from ref. 14).

shown by X-ray structures, ${ }^{12,13}$ in addition to binding the fucose residue on the $\mathrm{Ca}^{2+}$ site, DC-SIGN is uniquely able to stabilize $\mathrm{Le}^{\mathrm{X}}$ galactose residue in a second binding area due to key residues that are absent in Langerin.

The existence of a secondary binding site is also suggested by a glycan array study of over 100 glycan structures. ${ }^{12}$ This study demonstrated that the presence of a terminal fucose residue is not sufficient for DC-SIGN binding, but 14 fucose-bearing glycans with the structure of Lewis epitopes were found to bind selectively to DC-SIGN relative to L-SIGN.

We have recently described the first fucose-based artificial ligand of DC-SIGN (compound 2, Fig. 1), designed to mimic this trisaccharide. ${ }^{14}$ The ligand was built by using an $\alpha$-fucosylamide anchor to drive the molecule to the DC-SIGN primary binding site and connecting it to a galactose mimic using a cyclic cis- $\beta$ amino acid $((1 S, 2 R)$-2-amino-cyclohexanecarboxylic acid, Fig. 1$)$. The layout of these residues and more specifically the linker $\beta$ amino acid allowed the molecule to adopt a three-dimensional shape similar to the $\mathrm{Le}^{\mathrm{X}}$ trisaccharide (Fig. 1). ${ }^{15}$ Amide bonds were chosen to connect the three elements of ligand $\mathbf{2}$ to achieve synthetic simplicity as well as chemical and metabolic stability of the target molecule. DC-SIGN binding studies performed by SPR showed that ligand $\mathbf{2}$ and surprisingly its simplified version 3a, which does not contain the galactose-mimic moiety, inhibit DC-SIGN better than the natural ligand $1\left(\mathrm{IC}_{50}=0.35 \mathrm{mM}\right.$, $0.5 \mathrm{mM}$ and $0.8 \mathrm{mM}$, respectively). ${ }^{14}$ The weak difference of affinity between $\mathbf{2}$ and $\mathbf{3 a}$, however, suggested that the galactoselike fragment in $\mathbf{2}$ gives a limited contribution to the binding interaction. Building on this knowledge, the goals of the work we report in this paper were: 1) to establish a minimal structure easily accessible in large scale and able to engage the receptor with an affinity similar to that of the natural ligand $\mathrm{Le}^{\mathrm{x}}$;2) to improve the binding affinity of the fucosylamides by optimizing the interactions in the secondary binding site. To achieve these goals, a library of $c a .40$ derivatives of general formula $\mathbf{4}$ was designed, synthesized and assayed by SPR to determine the ability of the compounds to inhibit DC-SIGN binding to immobilized mannosylated Bovine Serum Albumin (Man-BSA). Moreover, a preliminary selectivity screening was introduced to test some library members for inhibition of Langerin, using SPR. Selectivity for DC-SIGN versus Langerin is specially important to develop inhibitors of sexually transmitted HIV infections. As discussed above, interaction with DC-SIGN on mucosal DC is used by the virus to invade the host immune system. On the contrary, Langerin is suggested to have protective effects against HIV infection. ${ }^{16}$ Indeed, some of the fucosylamides examined displayed an interesting DC-SIGN selectivity and have the potential of being developed as antiviral agents.

\section{Results and discussion}

In order to select reasonable ligand candidates, the properties of the protein surface in the vicinity of the $\mathrm{Ca}^{2+}$ site in the Lewis ${ }^{\mathrm{x}}$ DC-SIGN complex (1SL5) $)^{12}$ were examined using GRID. ${ }^{17}$ Both the DRY probe and the WATER probe were used to identify hydrophilic and lipophilic regions of the binding site. The molecular representations shown in Fig. 2 were obtained with the Maestro graphical interface. Various minima for the WATER probe were identified in the vicinity of the $\mathrm{Ca}^{2+}$-binding region: in the crystal structure, they are occupied by crystallographic water molecules W13, W34 and W36 (Fig. 2a). W13 and W36 are located in two well-defined low interaction energy sites, both below $-11 \mathrm{kcal} \mathrm{mol}{ }^{-1}$. W13 is in the vicinity of the fucose residue and mediates the interaction of Fuc-O2 with Glu354 and Lys368, and of Gal-O6 with Asp367 (Fig. 2a). W36 mediates the interaction of Gal-O4 with Glu358. The W36 site is occupied by a crystallographic water molecule also in 3 out of 4 known $\mathrm{X}$-ray structures of DC-SIGN in complex with oligomannosides $\left(1 \mathrm{SL} 4,{ }^{12} 1 \mathrm{~K} 9 \mathrm{I},{ }^{18} 2 \mathrm{IT} 5^{19}\right)$ and it is replaced by one sugar hydroxyl group in the fourth one $\left(2 \mathrm{IT} 6^{19}\right)$. The W34 site belongs to a larger isoenergetic area with a less favorable GRID interaction energy (ca. $-7 \mathrm{kcal} \mathrm{mol}^{-1}$ ), occupied by water molecules in 2 out of 4 oligomannoside-DC-SIGN complexes (1SL4, 1K9I) and loosely

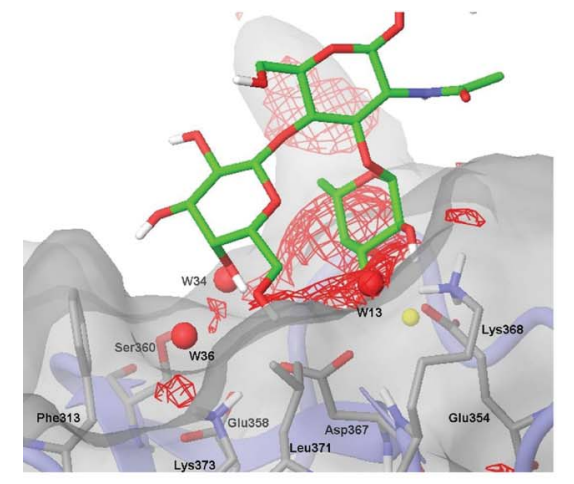

a.

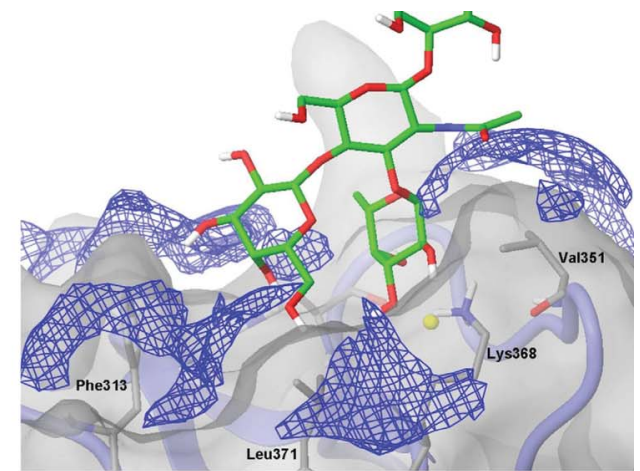

b.

Fig. 2 Energetic maps of GRID interactions (the $\mathrm{Ca}^{2+}$ ion is shown in yellow) in the structure of the DC-SIGN- Le ${ }^{\mathrm{x}}$ complex (pdb code : 1SL5, from ref. 11). a) WATER probe, $-7.0 \mathrm{kcal} \mathrm{mol}^{-1}$ isosurface, showing the binding sites for crystallographic water molecules W13, W34 and W36 in 1 SL5. b) DRY probe, $-0.5 \mathrm{kcal} \mathrm{mol}^{-1}$ isosurface, showing hydrophobic areas near the binding region and the groove formed by Phe 313 and Leu 371 . 

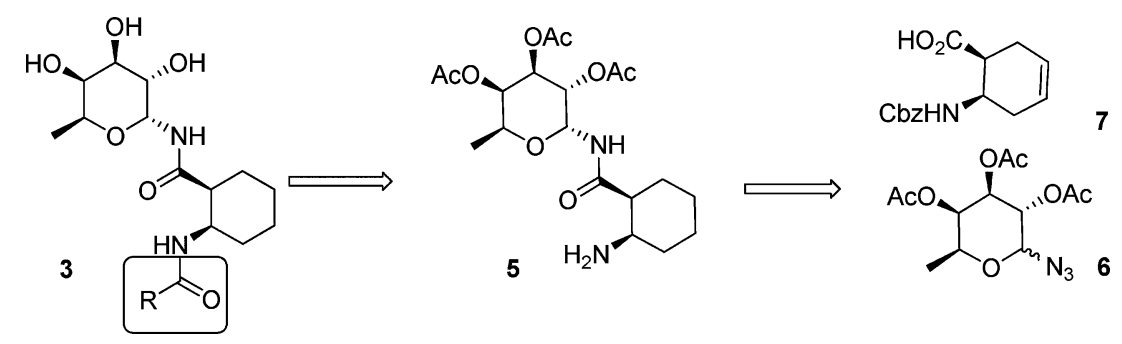

Scheme 1 Retrosynthetic analysis of fucosyl derivative $\mathbf{3}$.

replaced by mannose hydroxyl groups in the other 2 (2IT5 and 2IT6). In the 1SL5 structure, W34 mediates binding of Gal-O4 to Ser360 and, together with W36, contributes to the creation of a secondary binding site involving Leu371, Asp367, Lys373, Glu358 and flanked by Phe313 (Fig. 2a).

GRID analysis with the DRY probe allowed identification of the hydrophobic areas near the binding region, which are shown in Fig. 2b. Two of them, formed by Val351 and Asn362/Asn344, are in the immediate vicinity of the $\mathrm{Ca}^{2+}$-binding site and establish Van der Waals contact with the ligand. Phe313 and Leu371/Lys368 side chains form a major hydrophobic groove which flank the W36 crystallographic site.

Docking of mimic 2 in the 1SL5 structure was obtained using Glide. ${ }^{20}$ The complex, which included protein, ligand and the two water molecules W13 and W36, was prepared with the standard Preparation Wizard routine of Glide, but the final minimization was performed in implicit $\left(\mathrm{GB} / \mathrm{SA}^{21}\right)$ water with the AMBER* force field. It was found that this procedure allowed achievement of a better orientation of the water molecules and optimization of their hydrogen bonding pattern, which in turn avoided steric clashes in the following re-docking step. Docking obtained with this model suggested that optimal interaction is reached with the ligand in an extended conformation, which would allow the galactose mimic to place two hydroxyl groups in a hydrophilic patch of the protein near the side chain of Phe313 while nesting the cyclohexane ring in the groove formed by Phe 313 and Leu371 (Fig. 3).

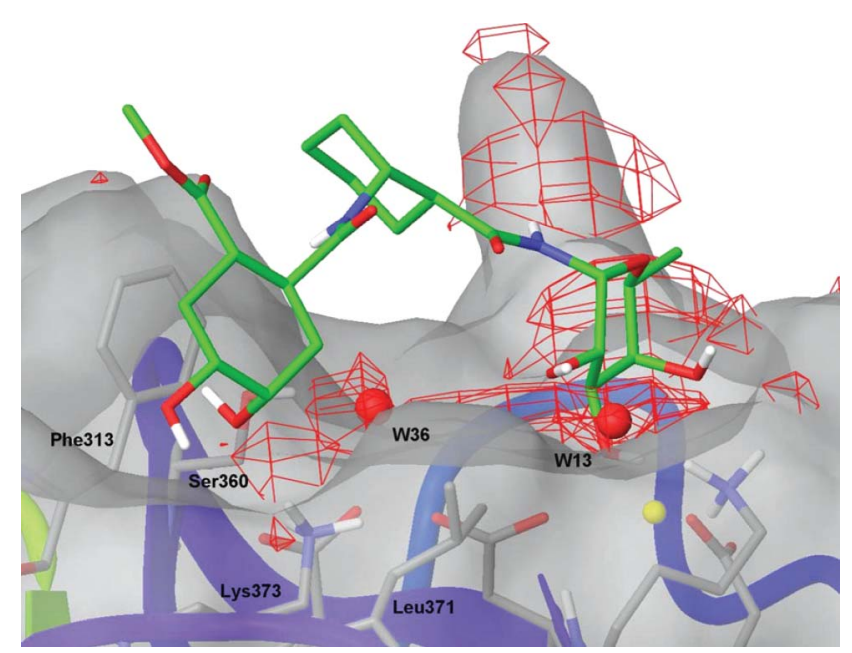

Fig. 3 Docking of mimic 2 in 1SL5. (the $\mathrm{Ca}^{2+}$ ion is shown in yellow).

Based on this model, interesting candidates to replace the galactose moiety should be molecules able to take advantage of lipophilic interactions and to interact specifically with the secondary hydrophilic regions. Further docking experiments suggested that favorable interactions could also be established by positively charged groups in the ligands and the negatively charged regions of the protein created by Asp 367 and Glu 358 side chains. Following this analysis, candidates for the $\mathrm{R}$ group in 4 were selected among commercially available carboxylic acids featuring aromatic groups and/or hydroxyl groups, amino groups or acetamides.

The initial set of compounds were synthesized starting from amine $5,{ }^{14}$ which in turn was obtained from tri- $O$-acetyl-Lfucosylazide $\mathbf{6}$ and the protected $(1 S, 2 R)$ - $\beta$-amino acid 7 , as we have previously described (Scheme 1). ${ }^{14}$

The coupling reactions between amine $\mathbf{5}$ and the acid partners $\left(\mathrm{RCO}_{2} \mathrm{H}\right.$, Scheme 2$)$ were performed using either HBTU, acid chloride or EDC/HOBt activation, as described in the Supplementary Information. These conditions afforded the protected ligands 8 in variable yields (between 43 and $80 \%$ ) after isolation by solid phase extraction and chromatographic purification. Removal of the protecting groups under standard Zemplen's conditions gave the required compounds 3 . If the acid partner carried a Boc protection, this was first removed using a mixture of TFA/ $\mathrm{CH}_{2} \mathrm{Cl}_{2}$ $(1 / 5)$. In this way $c a$. 30 different compounds were prepared (see Supplementary Information for the structure and characterization of the entire library). Scheme 2 shows the structure of those that will be used in the following discussion.

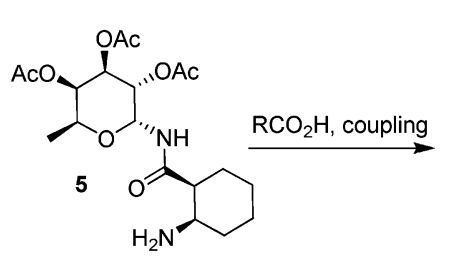<smiles>[R]C(=O)N[C@H]1CCCC[C@H]1C(=O)N[C@H]1O[C@H](C)[C@@H](OC(C)C)[C@H](OC(C)=O)[C@H]1OC(C)=O</smiles>
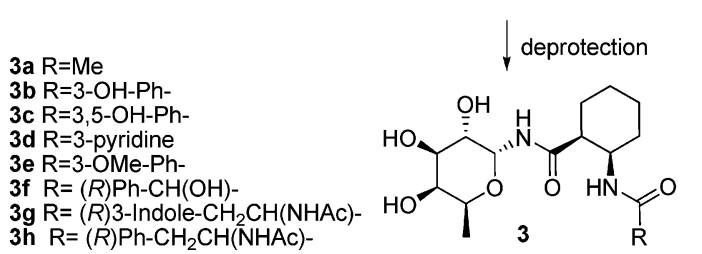

Scheme 2 Coupling reaction of amine 5 with acid partners

DC-SIGN affinity for the entire set of 30 compounds of general formula 3 was estimated using a surface plasmon resonance (SPR) biosensor in a competition assay which we have previously described ${ }^{14}$ The assay allows an affinity evaluation of all ligands relative to one another on the basis of their percentage inhibition 

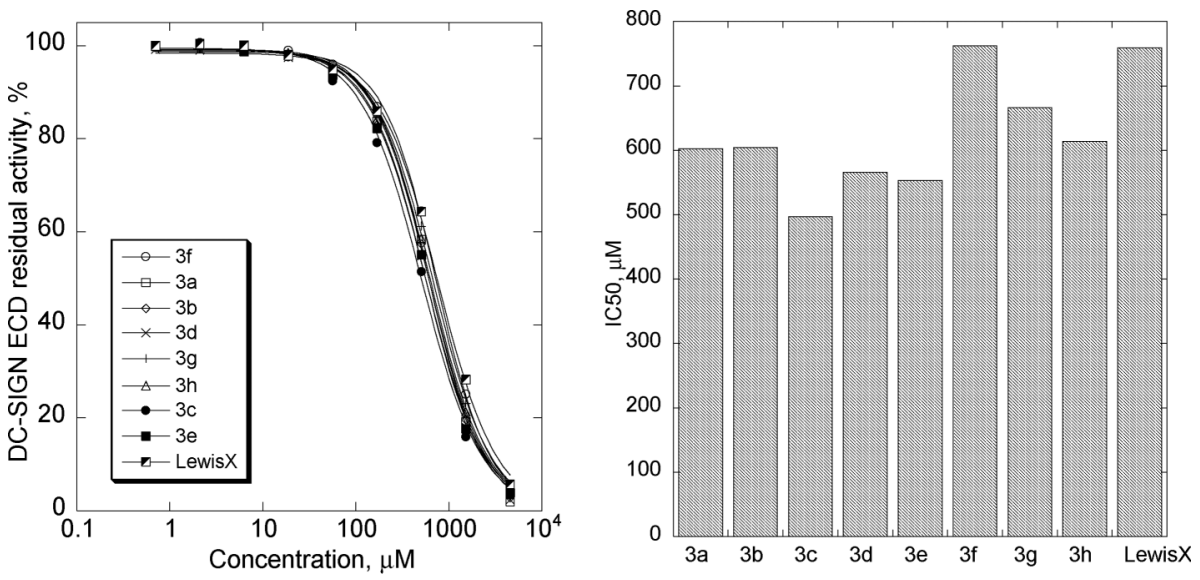

Fig. 4 The dependency of DC-SIGN ECD percent activity on concentrations of corresponding compounds. (see original sensorgrams in SI-Fig.4).

of DC-SIGN binding to immobilized mannosylated bovine serum albumin (Man-BSA). The commercially available Man-BSA used in these assays contain an average of 12 glycosylation sites displaying the Mano1-3[Mano1-6] Man branched trisaccharide. Man-BSA was covalently attached to a carboxymethyl dextranfunctionalized gold SPR sensor chip CM4. Inhibition studies were then performed using extracellular domain (ECD) of DCSIGN $(20 \mu \mathrm{M})$ injected alone or in the presence of a constant concentration $(300 \mu \mathrm{M})$ of the ligands. At this concentration, for the particular chip used in the assay, $\mathrm{Le}^{\mathrm{X}}$ exhibited $25 \%$ of inhibition. All the molecules 3 synthesized showed a similar efficiency, independent of the nature of the R group, and none improved significantly over the activity of $\mathbf{3 a}$. To confirm these data, complete inhibition curves were obtained and $\mathrm{IC}_{50}$ values were estimated for the selected group of compounds $\mathbf{3} \mathbf{a}-\mathbf{h}$ shown in Scheme 2. The results were totally consistent with the previous observation (Fig. 4).

Interestingly, when an analogous group of compounds 9 (Fig. 5), obtained by reaction of fucosylazide $\mathbf{6}$ with $\beta$-alanine rather than with 7, was examined in SPR single point assays at $300 \mu \mathrm{M}$ concentration, similar inhibition values $(25-30 \%)$ were obtained. Thus, these simple $\alpha$-fucosyl- $\beta$-alanyl amides showed a similar affinity for DC-SIGN as $\mathrm{Le}^{\mathrm{x}}$ and all the compounds $\mathbf{3}$ synthesized.
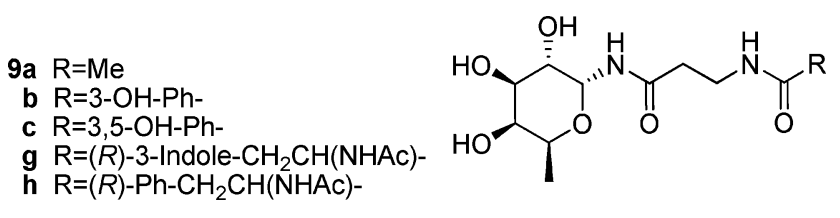

Fig. $5 \beta$-Alanine derivatives 9.

These observations, that are in striking contrast with the expectations derived from docking studies, strongly suggest that the $\mathrm{R}$ substituent in $\mathbf{3}$ is not reaching the secondary binding site identified by the docking algorithm and may not be interacting at all with the protein. The unexpected results obtained with $\alpha-$ fucosyl- $\beta$-alanyl amides $\mathbf{9}$, whilst providing us with very simple ligands of high efficiency, ${ }^{22}$ confirm that the $(1 S, 2 R)$-2-aminocyclohexanecarboxylic acid scaffold selected for the synthesis of $\mathbf{3}$ does not enforce optimal interaction of the secondary residue with the protein. NMR studies are currently in progress to assess the structural details of the interaction of DC-SIGN with compounds 3. ${ }^{23}$ To further explore the role of the $\beta$-amino acid structure in defining ligand-protein interaction, the configuration of the scaffold was varied systematically and a third set of compounds was synthesized, where the $\mathrm{R}$ fragment was kept unchanged and the $\beta$-configuration was systematically permutated.

The new set of compounds 10-12 (Fig. 6) were synthesized starting from $\beta$-amino acids 13-15 (Fig. 6) using the synthetic sequence employed for 3 and shown in Schemes 1 and 2. The syntheses of the enantiomerically pure isomeric amino acids 13-15 and of the corresponding fucosylamide derivatives 10-12 are described in the Supplementary Information. The $\mathrm{IC}_{50} \mathrm{ob}-$ tained by SPR analysis of 10-12 are collected in Fig. 7 and compared to selected data obtained for $\mathbf{3}$, for $\mathrm{Le}^{\mathrm{x}}$ and for $\mathrm{L}$-fucose (see SI-Fig 5 for original sensorgrams).

The $\mathrm{IC}_{50}$ values obtained for $\mathbf{3} \mathbf{a}$ and $\mathbf{3 b}$ are consistent with previous measurements (Fig. 4). The data confirm that the activity of most fucosylamides is close to that of $\mathrm{Le}^{\mathrm{x}}$. The series of compounds 10a-d show a larger increase of the affinity (a factor of 3) on passing from the acetamide $10 \mathrm{a}(\mathrm{R}=\mathrm{Me})$ to the aromatic amides 10b-d, suggesting a possible role of the aromatic group in the interaction with the protein. This series, which is built on the $(1 R, 2 S)$-2-amino-cyclohexanecarboxylic acid scaffold $\mathbf{1 3}$, also contains the strongest ligands so far, the hydroxybenzoic acid derivatives 10b and 10c $\left(\mathrm{IC}_{50} 470 \mu \mathrm{M}\right)$ and is therefore the best current candidate for further optimization.

To analyze the selectivity properties of the compounds screened, we developed an additional SPR analysis for Langerin binding properties. As for DC-SIGN, the ability of Langerin to bind to a surface functionalized with Man-BSA was tested. In the case of Langerin, binding to Man-BSA as well as to the dextran matrix (SI-Fig 1) was observed. Therefore, the dextran/Man-BSA surface was considered as a combined ligand of Langerin ECD. Upon titration of the surface with Langerin, a similar saturation curve than for DC-SIGN was obtained (SI-Fig. 2 and 3). Langerin displayed an apparent $K_{\mathrm{d}}$ for this surface of $10.3 \mu \mathrm{M}$. Indeed, the two lectins exhibited comparable affinity for this surface, thus the same fixed concentration of Langerin was used in the SPRbased competition assay, which allowed a direct comparison of the binding inhibition properties of the compounds for Langerin versus DC-SIGN. 
<smiles>[R]C(=O)N[C@H]1CCCC[C@H]1C(=O)N[C@H]1O[C@H](C)[C@@H](O)[C@H](O)[C@H]1O</smiles>

(1S, 2R)

3a $\mathrm{R}=\mathrm{Me}$

3b $\mathrm{R}=3-\mathrm{OH}-\mathrm{Ph}-$

3c $\mathrm{R}=3,5-\mathrm{OH}-\mathrm{Ph}$ -

3d $R=3$-pyridine

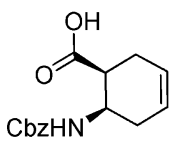

$7(1 S, 2 R)$

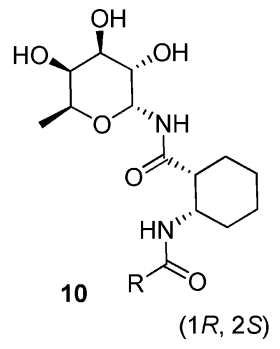

10a $\mathrm{R}=\mathrm{Me}$

10b R=3-OH-Ph10c $\mathrm{R}=3,5-\mathrm{OH}-\mathrm{Ph}$ 10d $R=3$-pyridine

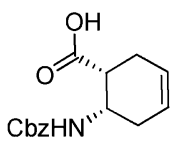

$13(1 R, 2 S)$<smiles>[R]C(=O)N[C@H]1CCCC[C@H]1C(=O)N[C@H]1O[C@H](C)[C@@H](O)[C@H](O)[C@H]1O</smiles>

11a $\mathrm{R}=\mathrm{Me}$ $11 \mathrm{~b}=3-\mathrm{OH}-\mathrm{Ph}-$ 11c $\mathrm{R}=3,5-\mathrm{OH}-\mathrm{Ph}-$<smiles>O=C(O)N[C@@H]1CC=CC[C@H]1C(=O)O</smiles>

$14(1 S, 2 S)$<smiles>[R]C(=O)N[C@H]1CCCC[C@H]1C(=O)N[C@H]1O[C@H](C)[C@@H](O)[C@H](O)[C@H]1O</smiles>

$(1 R, 2 R)$

12b $\mathrm{R}=3-\mathrm{OH}-\mathrm{Ph}-$<smiles>O=C(O)N[C@@H]1CC=CC[C@H]1C(=O)O</smiles>

$15(1 R, 2 R)$

Fig. 6 Library of compounds with different stereochemistry in the cyclohexane scaffold.
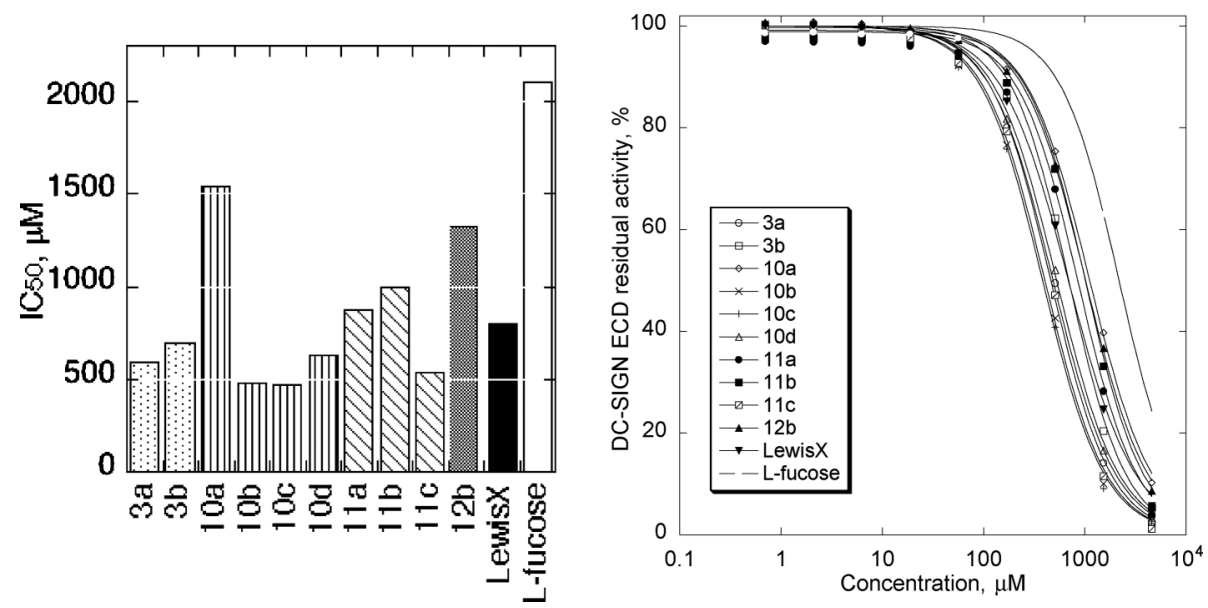

Fig. 7 The $\mathrm{IC}_{50}$ values obtained for compounds 10-12 by SPR inhibition assay. $\mathrm{IC}_{50}$ of $\mathrm{L}$-fucose, $\mathrm{Le}^{\mathrm{x}}, \mathbf{3 a}$ and $\mathbf{3 b}$ measured in the same conditions are shown for comparison.

Compounds initially tested for their DC-SIGN inhibitory potency (Fig. 7) were evaluated with Langerin ECD. The results are shown in Fig. 8A (see also SI-Fig.6). The inhibitory potency of the fucosylated mimics is so low against Langerin that it was not possible to determine an $\mathrm{IC}_{50}$. A crude comparison of the inhibitors' properties towards DC-SIGN and Langerin was obtained by comparing the residual activity of both lectins at the highest concentration tested for each compound (Fig. 8B).

The data show that many of the fucosylamides tested display a larger DC-SIGN selectivity than $\mathrm{Le}^{\mathrm{x}}$ and confirm $\mathbf{1 0 b}$ as one of the most interesting elements of this group, both for its DC-SIGN affinity and for its specificity.

\section{Conclusions}

In this paper, we have presented a new library of fucose-based ligands of DC-SIGN, all characterized by the presence of a $\beta$ amino acid tether and of a fucosylamide anchor, able to direct the molecules to the DC-SIGN CRD binding site. We were able to identify many compounds that, compared to the natural ligand $\mathrm{Le}^{\mathrm{x}}$ and its previously reported mimic 2, display a similar DCSIGN inhibition efficiency at a fraction of the synthetic cost. In particular, $\alpha$-fucosylamides 9 , derived from $\beta$-alanine, are interesting candidates for polyvalent presentations ${ }^{8 d-k}$ due to their high synthetic accessibility and good ligand efficiency. ${ }^{22} \mathrm{~A}$ second group of compounds, $\alpha$-fucosylamides 10 derived from $(1 R, 2 S)$ 2-amino-cyclohexanecarboxylic acid 13, were also of interest because they yielded the most active and selective ligand of this group (10b). Indeed, it may be important that molecules directed to block the action of DC-SIGN do not interfere with the action of other lectins. We have recently shown that $\alpha-N$-fucosylamides of general formula 3 and $\mathbf{9}$ interact strongly with the L-fucose binding lectin PA-IIL of Pseudomonas aeruginosa. ${ }^{24}$ In particular, to develop inhibitors of sexually transmitted HIV infections it may be necessary to select DC-SIGN antagonists that do not interfere with the action of Langerin. Like DC-SIGN, Langerin is a 

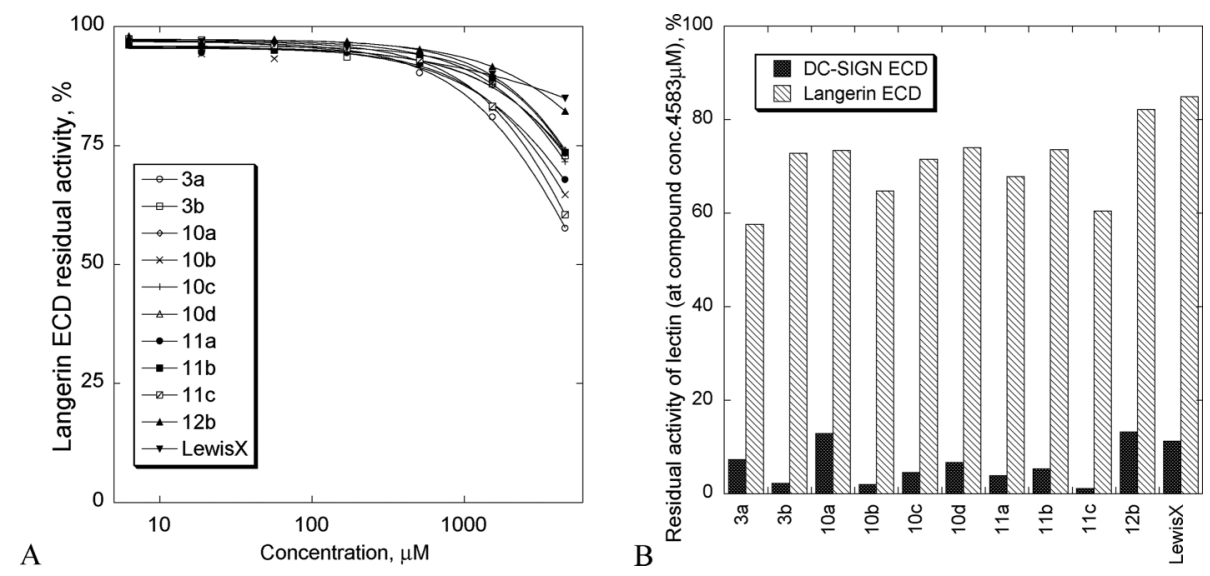

Fig. 8 A) Inhibition of Langerin ECD binding to Man-BSA immobilized on the dextran surface. B) Residual lectin activity at the highest tested concentration of the ligands $(4.6 \mathrm{mM})$. Langerin, white bars; DC-SIGN, black bars.

membrane C-type lectin known to bind to HIV-1. However, whilst interaction with DC-SIGN is used by the virus to invade the host immune system, Langerin is suggested to have protective effects against HIV infection. ${ }^{16,25}$ Indeed, Langerhans cells, which are the first dendritic cells to encounter HIV via genital mucosa, have been described as a natural barrier for HIV-1 transmission, which is dependent on Langerin expression..$^{15}$ The importance of Langerin in HIV protection has been again emphasized in the context of HIV-1/Herpes Simplex Virus type II (HSV-2) co-infection. ${ }^{26}$ In this last case, it has been demonstrated that HIV susceptibility of Langerhans cells, and the subsequent virus transmission, could be promoted by HSV-2-dependent abrogation of Langerin's functions. Conversely, DC-SIGN has a well-established role in dendritic cells-mediated HIV-1 transmission. ${ }^{6}$ Thus, the selectivity of the ligands for DC-SIGN relative to Langerin was also tested. Indeed, we described here for the first time, simultaneous screening of artificial compounds towards both lectins. In agreement with literature data on the natural ligands of these lectins, a low inhibitory potency of $\mathrm{Le}^{\mathrm{x}}$ towards Langerin has been observed in contrast to DC-SIGN. The capacity of $\mathrm{Le}^{\mathrm{x}}$ and of the other fucosylated derivatives to inhibit Langerin binding is so low that we could not perform a full inhibition curve in a reasonable range of concentration. Therefore, selectivity of the fucose-based ligands tested was assessed by comparing residual lectin activity at the highest ligand concentration tested. Most of the $\alpha$-fucosylamides assayed were found to be more DC-SIGN selective than the natural ligand $\mathrm{Le}^{\mathrm{x}}$ and therefore they are more likely to be turned into therapeutically useful tools against sexually transmitted HIV infection. $^{8}$

\section{Experimental}

\section{Langerin and DC-SIGN ECD expression and purification}

Langerin ECD constructs (comprising residue 68-328) have been overexpressed using a pET30b derived vector in BL21(DE3) as described previously. ${ }^{27}$ The protein was expressed as inclusion body, refolded and purified to homogeneity in a functional form as already described. ${ }^{22}$ DC-SIGN ECD protein (residue 66-404) has been overexpressed and purified as described previously. ${ }^{5 a}$

\section{Surface plasmon resonance analysis}

All experiments were performed on a Biacore 3000 using functionalized CM4 sensor chips and the corresponding reagents from Biacore. Two flow cells were activated as previously described. ${ }^{28}$ Flow cell one was then blocked with $30 \mu \mathrm{L}$ of $1 \mathrm{M}$ ethanolamine and used as a control surface. The second one was treated with BSA-Mano1-3[Mano1-6]Man (ManBSA, Dextra) $\left(60 \mu \mathrm{g} \mathrm{m}^{-1}\right)$ in $10 \mathrm{mM}$ acetate buffer, $\mathrm{pH} 4$. Remaining activated groups were blocked with $30 \mu \mathrm{L}$ of $1 \mathrm{M}$ ethanolamine. The final density immobilized on the surface of the second flow cell was $2000 \mathrm{RU}$. The Man-BSA used to functionalize CM4 chip harbours 12 glycosylation sites according to manufacturer.

Two types of SPR tests were set up for the evaluation of glycomimic compounds. The single point inhibition assay was used for fast screening of compound selectivity. Here, either DCSIGN or Langerin at concentration of $20 \mu \mathrm{M}$ were incubated with corresponding compounds ( $300 \mu \mathrm{M}$ final concentration) and $20 \mu \mathrm{l}$ of the samples were co-injected over Man-BSA surface. The lectin steady state binding responses were extracted from the sensorgrams and compared with the responses of compound-free lectin injections and converted to inhibition percent values. In the case of Langerin inhibition assay, even with parallel functionalization of the reference surface with non-glycosylated BSA, some interaction of Langerin with the dextran matrix still remains. Indeed, the dextran/Man-BSA surface has been considered as a combined ligand of Langerin ECD (see Supplementary Information for more details).

The second type of SPR test was used to estimate the relative compound affinity to the lectins on the basis of their IC50 values. This was accomplished in the same manner as in the single point inhibition assay, except that both lectins were incubated with increasing concentrations (from 0 to $5000 \mu \mathrm{M}$ ) of the corresponding compounds, the injected sample volumes were $13 \mu \mathrm{l}$, and the resulting binding responses were converted to residual lectin activity values, which were plotted against concentration values of the compounds. The relative IC50 values for each compound were determined by fitting four parameter logistic model (eqn (1)) to the experimental data. 


$$
y=\text { bot }+\frac{\text { top }- \text { bot }}{1+\left(\frac{x}{\mathrm{IC}_{50}}\right)^{\text {slope }}}
$$

where $y$ is the percent activity, $x$ is the corresponding concentration, bot and top are the lowest and the highest values of percent activity, respectively.

In both type of experiments $5 \mu$ flow rate was used and the running buffer was $25 \mathrm{mM}$ Tris- $\mathrm{HCl}, \mathrm{pH} 8,150 \mathrm{mM} \mathrm{NaCl}$, $4 \mathrm{mM} \mathrm{CaCl}$, and $0.005 \%$ of $\mathrm{P} 20$ surfactant. All the samples were prepared in the running buffer.

The stability of the surface during a campaign was evaluated by DC-SIGN ECD binding capacity as a function of the number of cycles. The chip surfaces demonstrated a strong stability with negligible decrease of the binding capacity of only $0.06 \%$ per cycle (see data in the Supplementary Information).

\section{Modeling}

Grid analysis. The properties of the protein surface in the vicinity of the $\mathrm{Ca}^{2+}$ site were determined using the protein crystal structure derived from the complex DC-SIGN-Le ${ }^{\mathrm{X}}$ (pdb code $1 \mathrm{SL}^{12}$ ) and the program GRID ${ }^{17}$ (version 22). In particular the DRY probe and the WATER probe were used to identify hydrophilic and lipophilic regions of the binding site. The accompanying program GREAT was used to check the crystal structure file and to prepare the file of coordinates in standard PDB format, which is used as an input for the program GRIN. This program, which prepares the input for the main program GRID, was used to automatically assign atom types and charges for every atom of the protein, using provided standard parameters. Calculations of the interaction energy between the probe and each atom of the protein were performed on a box $(36.6 \AA \times 23.0 \AA \times 16.6 \AA$ per side $)$ centered on the protein, with a grid spacing of $0.2 \AA(\mathrm{NPLA}=5)$ and its value was evaluated at each grid point. A dielectric constant of 80 was used to simulate a bulk aqueous phase, while a dielectric constant of 4 was assigned to the interior of the protein.

The output, which consists of an array of interaction energies, can be visualized as contour surfaces at appropriate energy levels together with the protein structure. Contours at negative energy levels delineate regions of attraction between probe and protein, whereas positive energy levels define the surface of the protein. Visual inspection of the contour surfaces superimposed on the active site of DC-SIGN enabled the identification of the most favored hydrophilic and lipophilic regions, facilitating the interpretation of protein-ligand interaction. Moreover interaction energy values between the WATER probe and the protein were used to identify the important structural water molecules out of all the crystallized water molecules found in the X-ray structure. An arbitrary cut-off of $-10.42 \mathrm{kcal} \mathrm{mol}^{-1}$ (the most negative energy value was $-14.97 \mathrm{kcal} \mathrm{mol}^{-1}$ ) was chosen to detect the most favorable hot spots for a water molecule. This cut off allowed us to identify two important structural water molecules, corresponding to $\mathrm{W} 13$ and $\mathrm{W} 36$ in the crystal structure of DC-SIGN-Le ${ }^{\mathrm{X}}$ complex (1SL5). The DC-SIGN crystal structure including these two water molecules was subsequently used for additional docking runs.
Docking calculations. Docking calculations were performed using the program GLIDE 4.5. ${ }^{20}$ The initial setup for the receptor preparation before docking runs was performed using Schrödinger's 'Protein Preparation Wizard', starting from the $\mathrm{X}$-ray crystal structure of the DC-SIGN-Le ${ }^{\mathrm{x}}$ complex. All crystallographic water molecules, except for W13 and W36, were deleted, bond orders assigned and hydrogen atoms added. The assignments of protonation states for basic and acidic residues were based on the optimization of hydrogen bonding patterns. The final minimization of the complex was not performed with the Preparation Wizard default, but the complex was minimized (500 steps, Truncated Newton Conjugate Gradient method) in implicit water $\left(\mathrm{GB} / \mathrm{SA}^{21}\right.$ model) using MacroModel ${ }^{29}$ with the AMBER* force field (dielectric constant 1, cut off extended, convergence on gradient with threshold of 0.05 ). The oxygen atoms of W13 and W36 as well as the $\mathrm{Ca}^{2+}$ ion were anchored to the original position through a harmonic potential during minimization. At the end of the minimization, the rootmean-square deviation (RMSD) of all heavy atoms was within $0.34 \AA$ of the crystallographic positions. Docking calculations were performed in Standard Precision mode with standard OPLS-AA $(2001)^{30}$ force field; non-planar conformations of amide bonds were penalized, Van der Waals radii were scaled by 0.80 and the partial charge cut off was fixed to 0.15 . The shape and properties of the binding site were mapped onto grids with dimensions of $36 \AA$ (enclosing box) and $14 \AA$ (ligand diameter midpoint box), centered on the ligand in the X-ray structure of the DC-SIGN-Le ${ }^{\mathrm{X}}$ complex. Docking was constrained in the $\mathrm{Ca}^{2+}$ binding site by specifying a reference core corresponding to the $\mathrm{C} 1-\mathrm{C} 6$ carbon and $\mathrm{O} 3-\mathrm{O} 4-\mathrm{O} 5$ oxygen atoms of the fucose residue of the reference ligand in the X-ray structure of the DC-SIGN-Le ${ }^{\mathrm{x}}$ complex: ligands that feature the same core moiety as the reference ligand are subject to the constraint. The RMSD tolerance for the position of the core was set to $3.5 \AA$. This parameter enforces the fucose moiety to be located within $3.5 \AA$ of the fucose residue in the reference ligand: ligand poses that do not match this constraint are screened out. These constraints allow coordination of the $\mathrm{Ca}^{2+}$ ion by the hydroxy groups $\mathrm{OH}-2$ and $\mathrm{OH}-3$ of fucose, as observed in several crystal structure of C-type lectins complexed with fucosecontaining ligands. The RMSD tolerance of $3.5 \AA$ was selected to allow docking poses to explore both possible binding modes of the vicinal diol. Indeed, crystallographic and NMR data on DC-SIGN show that the monosaccharide moiety of ligands can coordinate the $\mathrm{Ca}^{2+}$ ion with the vicinal hydroxyl groups in two possible orientations, differing by a $180^{\circ}$ rotation. The quality of this docking protocol was validated by re-docking the $\mathrm{Le}^{\mathrm{x}}$ ligand in the DC-SIGN-Le ${ }^{\mathrm{X}}$ complex, which yielded a ligand pose that could be superimposed with crystalline $\mathrm{Le}^{\mathrm{x}}$ with RMSD of $1.71 \AA$ (0.31 $\AA$ for the fucose residue).

\section{Synthesis}

Solvents were dried by standard procedures: dichloromethane, methanol, $N, N$-diisopropylethylamine and triethylamine were dried over calcium hydride, chloroform and pyridine were dried over activated molecular sieves. Reactions requiring anhydrous conditions were performed under nitrogen. ${ }^{1} \mathrm{H},{ }^{13} \mathrm{C}$ and ${ }^{31} \mathrm{P}$ NMR spectra were recorded at $400 \mathrm{MHz}$ on a Bruker AVANCE400 instrument. Chemical shifts $(\delta)$ for ${ }^{1} \mathrm{H}$ and ${ }^{13} \mathrm{C}$ spectra are 
expressed in ppm relative to internal $\mathrm{Me}_{4} \mathrm{Si}$ as standard. Signals are abbreviated as s, singlet; bs, broad singlet; $d$, doublet; $t$, triplet; q, quartet; m, multiplet. Mass spectra were obtained with a Bruker ion-trap Esquire 3000 apparatus (ESI ionization) or an Autospec Fission Instrument (FAB ionization). HRMS (FT-ICR, ESI) were obtained with an Apex II instrument. Thin layer chromatography (TLC) was carried out with pre-coated Merck $\mathrm{F}_{254}$ silica gel plates. Flash chromatography (FC) was carried out with MachereyNagel silica gel 60 (230-400 mesh). The libraries were synthesized through the common approach shown in Scheme 1. ${ }^{14}$ All synthetic schemes and procedures, the synthesis and characterization of new intermediates, the synthesis and characterization of the full library of ligands $\left(\mathbf{3}, 9,11\right.$ and 12) as well as their ${ }^{1} \mathrm{H}$ - and ${ }^{13} \mathrm{C}-\mathrm{NMR}$ spectra are collected in the Supplementary Information. Below we report the characterization of compounds $10 \mathbf{a}-\mathbf{d}$ (from $(1 R, 2 S)$ 2-aminocyclohexanecarboxylic acid). Compounds $\mathbf{3 a}$ and $\mathbf{5}$ were previously described. ${ }^{14}$

\section{$N$-((1R,2S)-2-Acetamido-cyclohexanecarboxyl)- $\alpha$-L-fucopyrano- sylamine (10a)}

The crude hydrogenation product of $\mathbf{2 8}$ (see Supplementary Information-SI-Scheme 3) was used in the general acetylation method (see Supplementary Information). The product was purified by flash chromatography on silica gel (AcOEt, $\left.R_{\mathrm{f}} 0.29\right)$. Yield: $27 \mathrm{mg}(82 \%)$. Zemplen deprotection and flash chromatography (85: $\left.15 \mathrm{CHCl}_{3}: \mathrm{MeOH}, R_{\mathrm{f}} 0.18\right)$ afforded 10a. Yield: $13 \mathrm{mg}(65 \%)$. ${ }^{1} \mathrm{H}-\mathrm{NMR}\left(400 \mathrm{MHz}, \mathrm{CD}_{3} \mathrm{OD}\right): \delta(\mathrm{ppm})=1.18\left(\mathrm{~d}, 3 \mathrm{H}, J_{5-6}=\right.$ $\left.6.5 \mathrm{~Hz}, \mathrm{H}_{\mathrm{F} 6}\right), 1.32-1.50\left(\mathrm{~m}, 2 \mathrm{H}, \mathrm{H}_{\mathrm{Cy} 4 a x}\right.$ and $\left.\mathrm{H}_{\mathrm{Cy} 5 \mathrm{ax}}\right), 1.55-1.68(\mathrm{~m}$, $3 \mathrm{H}, \mathrm{H}_{\mathrm{Cy} 6 \mathrm{ax}}, \mathrm{H}_{\mathrm{C} 3 \mathrm{ax}}$ and $\mathrm{H}_{\mathrm{C} 4 \mathrm{eq}}$ or $\left.\mathrm{H}_{\mathrm{C} 5 \mathrm{eq}}\right), 1.73-1.78\left(\mathrm{~m}, 1 \mathrm{H}, \mathrm{H}_{\mathrm{Cy} 4 \mathrm{eq}}\right.$ or $\left.\mathrm{H}_{\text {Cyseq }}\right), 1.83-1.92\left(\mathrm{~m}, 1 \mathrm{H}, \mathrm{H}_{\text {Cyзeq }}\right.$ and $\left.\mathrm{H}_{\mathrm{C6eq}}\right), 1.94$ (s, 3H, Ac-Me), 2.71-2.75 (m, 1H, $\left.\mathrm{H}_{\mathrm{Cy1} 1}\right), 3.63-3.66\left(\mathrm{~m}, 1 \mathrm{H}, \mathrm{H}_{\mathrm{F} 4}\right), 3.74\left(\mathrm{dd}, J_{3-4}=\right.$ $\left.3.3 \mathrm{~Hz}, J_{3-2}=10.3 \mathrm{~Hz}, 1 \mathrm{H}, \mathrm{H}_{\mathrm{F} 3}\right), 3.79\left(\mathrm{q}, J_{5-6}=6.5 \mathrm{~Hz}, 1 \mathrm{H}, \mathrm{H}_{\mathrm{F} 5}\right)$, $3.94\left(\mathrm{dd}, J_{1-2}=5.6 \mathrm{~Hz}, J_{2-3}=10.2 \mathrm{~Hz}, 1 \mathrm{H}, \mathrm{H}_{\mathrm{F} 2}\right), 4.18-4.25(\mathrm{~m}$, $\left.1 \mathrm{H}, \mathrm{H}_{\mathrm{Cy} 2}\right), 5.51\left(\mathrm{~d}, 1 \mathrm{H}, J_{1-2}=5.6 \mathrm{~Hz}, \mathrm{H}_{\mathrm{F} 1}\right) .{ }^{13} \mathrm{C}-\mathrm{NMR}(100 \mathrm{MHz}$, $\left.\mathrm{CD}_{3} \mathrm{OD}\right): \delta(\mathrm{ppm})=17.0\left(\mathrm{C}_{\mathrm{F} 6}\right), 23.0(\mathrm{Ac}-\mathrm{Me}), 23.6\left(\mathrm{C}_{\mathrm{Cy} 4}\right.$ or $\left.\mathrm{C}_{\mathrm{Cy} 5}\right)$, $24.2\left(\mathrm{C}_{\mathrm{Cy} 4}\right.$ or $\left.\mathrm{C}_{\mathrm{Cy} 5}\right), 26.8\left(\mathrm{C}_{\mathrm{Cy} 6}\right), 30.7\left(\mathrm{C}_{\mathrm{Cy} 3}\right), 40.3\left(\mathrm{C}_{\mathrm{Cy} 1}\right), 46.4\left(\mathrm{C}_{\mathrm{Cy} 2}\right)$, $68.3\left(\mathrm{C}_{\mathrm{F} 2}\right), 68.8\left(\mathrm{C}_{\mathrm{F} 5}\right), 71.8\left(\mathrm{C}_{\mathrm{F} 3}\right), 73.3\left(\mathrm{C}_{\mathrm{F} 4}\right), 78.3\left(\mathrm{C}_{\mathrm{F} 1}\right), 173.1$ (NHCO), 177.5 (NHCO). HRMS (FT-ICR, ESI): $m / z$ calcd for $\mathrm{C}_{15} \mathrm{H}_{26} \mathrm{~N}_{2} \mathrm{O}_{6}: 353.16831[\mathrm{M}+\mathrm{Na}]^{+}$; found: $353.16838 .[\alpha]_{\mathrm{D}}-77.5$ (c $0.35, \mathrm{EtOH})$

\section{$N-[(1 R, 2 S)-2-(3-H y d r o x y b e n z a m i d o) c y c l o h e x a n e c a r b o x y l]-\alpha-L-$ fucopyranosylamine (10b)}

The crude hydrogenation product of $\mathbf{2 8}$ (see Supplementary Information-SI-Scheme 3) was coupled with 3-hydroxybenzoic acid using the HBTU general procedure (see Supplementary Information) and the product was purified by flash chromatography (6:4 AcOEt:petroleum ether, $R_{\mathrm{f}}$ 0.38). Yield: $13 \mathrm{mg}$ (31\%). Zemplen deprotection and flash chromatography $(85: 15$ chloroform : methanol, $\left.R_{\mathrm{f}} 0.17\right)$ afforded 10b. Yield: $8 \mathrm{mg}(89 \%)$. ${ }^{1} \mathrm{H}-\mathrm{NMR}\left(400 \mathrm{MHz}, \mathrm{CD}_{3} \mathrm{OD}\right): \delta(\mathrm{ppm})=1.18\left(\mathrm{~d}, 3 \mathrm{H}, J_{5-6}=6.5 \mathrm{~Hz}\right.$, $\left.\mathrm{H}_{\mathrm{F} 6}\right), 1.42-1.55\left(\mathrm{~m}, 2 \mathrm{H}, \mathrm{H}_{\mathrm{Cy} 4 a x}\right.$ and $\left.\mathrm{H}_{\mathrm{Cy} 5 \mathrm{ax}}\right), 1.61-1.76\left(\mathrm{~m}, 4 \mathrm{H}, \mathrm{H}_{\mathrm{Cy} 6 \mathrm{ax}}\right.$, $\mathrm{H}_{\text {Cy3ax }}, \mathrm{H}_{\text {Cy4eq }}$ and $\left.\mathrm{H}_{\text {Cy5eq }}\right), 1.94-2.02\left(\mathrm{~m}, 1 \mathrm{H}, \mathrm{H}_{\text {Су6еq }}\right), 2.16-2.24(\mathrm{~m}$, $\left.1 \mathrm{H}, \mathrm{H}_{\text {Cyзeq }}\right), 2.86-2.91\left(\mathrm{~m}, 1 \mathrm{H}, \mathrm{H}_{\mathrm{Cy} 1}\right), 3.63-3.66\left(\mathrm{~m}, 1 \mathrm{H}, \mathrm{H}_{\mathrm{F} 4}\right), 3.74$ $3.80\left(\mathrm{~m}, 2 \mathrm{H}, \mathrm{H}_{\mathrm{F} 5}\right.$ and $\left.\mathrm{H}_{\mathrm{F} 3}\right), 3.91-3.95\left(\mathrm{~m}, 1 \mathrm{H}, \mathrm{H}_{\mathrm{F} 2}\right), 4.28-4.33(\mathrm{~m}$, $\left.1 \mathrm{H}, \mathrm{H}_{\mathrm{Cy} 2}\right), 5.52-5.54\left(\mathrm{~m}, 1 \mathrm{H}, \mathrm{H}_{\mathrm{F} 1}\right) 6.90-6.95(\mathrm{~m}, 1 \mathrm{H}, \mathrm{Ar}), 7.18-7.28$ (m, 3H, Ar). ${ }^{13} \mathrm{C}-\mathrm{NMR}\left(100 \mathrm{MHz}, \mathrm{CD}_{3} \mathrm{OD}\right): \delta(\mathrm{ppm})=17.0\left(\mathrm{C}_{\mathrm{F} 6}\right)$,
$23.8\left(\mathrm{C}_{\mathrm{Cy} 4}\right.$ or $\left.\mathrm{C}_{\mathrm{Cy} 5}\right), 24.2\left(\mathrm{C}_{\mathrm{Cy} 4}\right.$ or $\left.\mathrm{C}_{\mathrm{Cy} 5}\right), 27.8\left(\mathrm{C}_{\mathrm{Cy} 6}\right), 30.4\left(\mathrm{C}_{\mathrm{Cy} 3}\right), 46.2$ $\left(\mathrm{C}_{\mathrm{Cy} 1}\right), 50.2\left(\mathrm{C}_{\mathrm{Cy} 2}\right), 68.2\left(\mathrm{C}_{\mathrm{F} 2}\right), 68.8\left(\mathrm{C}_{\mathrm{F} 5}\right), 71.7\left(\mathrm{C}_{\mathrm{F} 3}\right), 73.3\left(\mathrm{C}_{\mathrm{F} 4}\right)$, $78.4\left(\mathrm{C}_{\mathrm{F} 1}\right), 115.3$ (Ar), 119.4 (Ar), 119.7 (Ar), 130.8 (Ar), 137.5 $\left(\mathrm{C}_{\text {quart.Ar. }}\right), 158.9$ ( $\left.\mathrm{C}_{\text {quart.Ar. }}\right), 170.0$ (NHCO), 178.0 (NHCO). HRMS (FT-ICR, ESI): $m / z$ calcd for $\mathrm{C}_{20} \mathrm{H}_{28} \mathrm{~N}_{2} \mathrm{O}_{7}: 431.17887[\mathrm{M}+\mathrm{Na}]^{+}$; found: $431.17948 .[\alpha]_{\mathrm{D}}-53.1(c 0.25, \mathrm{MeOH})$

\section{$N$-[(1R,2S)-2-(3,5-Dihydroxybenzamido)cyclohexanecarboxyl]- $\alpha-$ L-fucopyranosylamine (10c)}

The crude hydrogenation product of $\mathbf{2 8}$ (see Supplementary Information-SI-Scheme 3) was coupled with 3,5dihydroxybenzoic acid using the HBTU general procedure (see Supplementary Information) and the product was purified by flash chromatography ( $7: 3$ ethyl acetate : n-hexane, $R_{\mathrm{f}} 0.43$ ). Yield: $17 \mathrm{mg}(37 \%)$. Zemplen deprotection and flash chromatography ( $85: 15$ chloroform : methanol, $\left.R_{\mathrm{f}} 0.14\right)$ afforded 10c. Yield: $10 \mathrm{mg}$ (91\%). ${ }^{1} \mathrm{H}-\mathrm{NMR}\left(400 \mathrm{MHz}, \mathrm{CD}_{3} \mathrm{OD}\right): \delta(\mathrm{ppm})=1.19(\mathrm{~d}, 3 \mathrm{H}$, $\left.J_{5-6}=6.5 \mathrm{~Hz}, \mathrm{H}_{\mathrm{F} 6}\right), 1.42-1.55\left(\mathrm{~m}, 2 \mathrm{H}, \mathrm{H}_{\mathrm{Cy} 4 \mathrm{ax}}\right.$ and $\left.\mathrm{H}_{\mathrm{Cy} 5 \mathrm{ax}}\right), 1.61-1.73$ (m, 4H, $\mathrm{H}_{\mathrm{C6ax}}, \mathrm{H}_{\text {Cy3ax }}, \mathrm{H}_{\text {Cy4eq }}$ and $\mathrm{H}_{\text {Cyeq }}$ ), 1.92-2.02 (m, 1H, $\mathrm{H}_{\text {Cу6еq }}$ ), 2.16-2.22 (m, 1H, $\left.\mathrm{H}_{\text {Сузеq }}\right), 2.85-2.90\left(\mathrm{~m}, 1 \mathrm{H}, \mathrm{H}_{\mathrm{Cy1}}\right), 3.64-3.66(\mathrm{~m}$, $\left.1 \mathrm{H}, \mathrm{H}_{\mathrm{F} 4}\right), 3.77\left(\mathrm{dd}, J_{3-4}=3.3 \mathrm{~Hz}, J_{2-3}=10.3 \mathrm{~Hz}, 1 \mathrm{H}, \mathrm{H}_{\mathrm{F} 3}\right), 3.79$ $\left(\mathrm{q}, J_{5-6}=6.5 \mathrm{~Hz}, 1 \mathrm{H}, \mathrm{H}_{\mathrm{F} 5}\right), 3.95\left(\mathrm{dd}, 1 \mathrm{H}, J_{1-2}=5.6 \mathrm{~Hz}, J_{2-3}=\right.$ $\left.10.3 \mathrm{~Hz}, \mathrm{H}_{\mathrm{F} 2}\right), 4.25-4.30\left(\mathrm{~m}, 1 \mathrm{H}, \mathrm{H}_{\mathrm{Cy} 2}\right), 5.55\left(\mathrm{~d}, 1 \mathrm{H}, J_{l-2}=5.6 \mathrm{~Hz}\right.$, $\left.\mathrm{H}_{\mathrm{F} 1}\right) 6.39$ (bs, 1H, Ar), 6.68 (bs, 2H, Ar). ${ }^{13} \mathrm{C}-\mathrm{NMR}(100 \mathrm{MHz}$, $\left.\mathrm{CD}_{3} \mathrm{OD}\right): \delta(\mathrm{ppm})=17.0\left(\mathrm{C}_{\mathrm{F} 6}\right), 23.8\left(\mathrm{C}_{\mathrm{Cy} 4}\right.$ or $\left.\mathrm{C}_{\mathrm{Cy} 5}\right), 24.1\left(\mathrm{C}_{\mathrm{Cy} 4}\right.$ or $\left.\mathrm{C}_{\mathrm{Cy} 5}\right), 27.9\left(\mathrm{C}_{\mathrm{Cy} 6}\right), 30.4\left(\mathrm{C}_{\mathrm{Cy} 3}\right), 46.2\left(\mathrm{C}_{\mathrm{Cy} 1}\right), 50.2\left(\mathrm{C}_{\mathrm{Cy} 2}\right), 68.2\left(\mathrm{C}_{\mathrm{F} 2}\right)$, $68.8\left(\mathrm{C}_{\mathrm{F} 3}\right.$ or $\left.\mathrm{C}_{\mathrm{F} 5}\right), 71.7\left(\mathrm{C}_{\mathrm{F} 3}\right.$ or $\left.\mathrm{C}_{\mathrm{F} 5}\right), 73.3\left(\mathrm{C}_{\mathrm{F} 4}\right), 78.4\left(\mathrm{C}_{\mathrm{F} 1}\right), 106.8$ (Ar), 106.8 (Ar), 138.1 (Cquart., Ar.), 160.0 (Cquart., Ar.), 170.0 (NHCO), 178.0 (NHCO). HRMS (FT-ICR, ESI): $m / z$ calcd for $\mathrm{C}_{20} \mathrm{H}_{28} \mathrm{~N}_{2} \mathrm{O}_{8}$ : $447.17379[\mathrm{M}+\mathrm{Na}]^{+}$; found: 447.17407. $[\alpha]_{\mathrm{D}}-65.7$ (c $0.20, \mathrm{MeOH})$

\section{$N$-[(1R,2S)-2-(3-Pyridinecarboxamido)cyclohexanecarboxyl]-a- L-fucopyranosylamine (10d)}

The crude hydrogenation product of $\mathbf{2 8}$ (see Supplementary Information-SI-Scheme 3) was coupled with nicotinic acid using the HBTU general procedure (see Supplementary Information) and the product was purified by flash chromatography (97:3 ethyl acetate: triethyl amine, $\left.R_{\mathrm{f}} 0.17\right)$. Yield: $19 \mathrm{mg}$ $(50 \%)$ Zemplen deprotection and flash chromatography $(85: 15$ chloroform : methanol, $\left.R_{\mathrm{f}} 0.17\right)$ afforded 10d. Yield: $6 \mathrm{mg}(43 \%)$. ${ }^{1} \mathrm{H}-\mathrm{NMR}\left(400 \mathrm{MHz}, \mathrm{CD}_{3} \mathrm{OD}\right): \delta(\mathrm{ppm})=1.19\left(\mathrm{~d}, 3 \mathrm{H}, J_{5-6}=6.5 \mathrm{~Hz}\right.$, $\left.\mathrm{H}_{\mathrm{F} 6}\right), 1.43-1.55\left(\mathrm{~m}, 2 \mathrm{H}, \mathrm{H}_{\mathrm{Cy} 4 a x}\right.$ and $\left.\mathrm{H}_{\mathrm{Cy} 5 \mathrm{ax}}\right), 1.67-1.78\left(\mathrm{~m}, 4 \mathrm{H}, \mathrm{H}_{\mathrm{Cy} 6 \mathrm{ax}}\right.$, $\mathrm{H}_{\text {Су3аx }}, \mathrm{H}_{\text {Су4еq }}$ and $\left.\mathrm{H}_{\mathrm{C} 5 \mathrm{eq}}\right), 1.94-2.04\left(\mathrm{~m}, 1 \mathrm{H}, \mathrm{H}_{\mathrm{Cy3eq}}\right), 2.14-2.21(\mathrm{~m}$, $\left.1 \mathrm{H}, \mathrm{H}_{\text {Субеq }}\right), 2.88-2.92\left(\mathrm{~m}, 1 \mathrm{H}, \mathrm{H}_{\mathrm{Cyl}}\right), 3.63-3.66\left(\mathrm{~m}, 1 \mathrm{H}, \mathrm{H}_{\mathrm{F} 4}\right), 3.74$ $\left(\mathrm{dd}, J_{3-4}=3.4 \mathrm{~Hz}, J_{2-3}=10.3 \mathrm{~Hz}, 1 \mathrm{H}, \mathrm{H}_{\mathrm{F} 3}\right), 3.78\left(\mathrm{q}, J_{5-6}=6.5 \mathrm{~Hz}\right.$, $\left.1 \mathrm{H}, \mathrm{H}_{\mathrm{F} 5}\right), 3.93\left(\mathrm{dd}, 1 \mathrm{H}, J_{l-2}=5.6 \mathrm{~Hz}, J_{2-3}=10.2 \mathrm{~Hz}, \mathrm{H}_{\mathrm{F} 2}\right), 4.37-4.42$ $\left(\mathrm{m}, 1 \mathrm{H}, \mathrm{H}_{\mathrm{Cy} 2}\right), 5.53\left(\mathrm{~d}, 1 \mathrm{H}, J_{l-2}=5.6 \mathrm{~Hz}, \mathrm{H}_{\mathrm{F} 1}\right), 7.50-7.53(\mathrm{~m}, 1 \mathrm{H}$, $\left.\mathrm{H}_{\mathrm{Ar} 5}\right), 8.20\left(\mathrm{~d}, 1 \mathrm{H}, J_{A r 5}-J_{A r 6}=8.0 \mathrm{~Hz}, \mathrm{H}_{\mathrm{Ar} 6}\right), 8.65\left(\mathrm{~d}, 1 \mathrm{H}, J_{A r 4}-J_{A r 5}=\right.$ $\left.4.5 \mathrm{~Hz}, \mathrm{H}_{\mathrm{Ar} 4}\right), 8.92\left(\mathrm{~s}, 1 \mathrm{H}, \mathrm{H}_{\mathrm{Ar} 2}\right) .{ }^{13} \mathrm{C}-\mathrm{NMR}\left(100 \mathrm{MHz}, \mathrm{CD}_{3} \mathrm{OD}\right)$ : $\delta(\mathrm{ppm})=17.0\left(\mathrm{C}_{\mathrm{F} 6}\right), 23.7\left(\mathrm{C}_{\mathrm{Cy} 4}\right.$ and $\left.\mathrm{C}_{\mathrm{Cy} 5}\right), 24.1\left(\mathrm{C}_{\mathrm{Cy} 3}\right), 27.4\left(\mathrm{C}_{\mathrm{Cy} 6}\right)$, $30.4\left(\mathrm{C}_{\mathrm{Cy} 1}\right), 50.4\left(\mathrm{C}_{\mathrm{Cy} 2}\right), 68.2\left(\mathrm{C}_{\mathrm{F} 2}\right), 68.8\left(\mathrm{C}_{\mathrm{F} 5}\right), 71.7\left(\mathrm{C}_{\mathrm{F} 3}\right), 73.3\left(\mathrm{C}_{\mathrm{F} 4}\right)$, $78.3\left(\mathrm{C}_{\mathrm{F} 1}\right), 125.1\left(\mathrm{C}_{\mathrm{Ar} 5}\right), 132.7\left(\mathrm{C}_{\text {quart.Ar }}\right), 137.4\left(\mathrm{C}_{\mathrm{Ar} 6}\right), 149.5\left(\mathrm{C}_{\mathrm{Ar} 2}\right)$, $152.5\left(\mathrm{C}_{\mathrm{Ar} 4}\right), 167.95$ (NHCO), 177.76 (NHCO). HRMS (FT-ICR, ESI): $m / z$ calcd for $\mathrm{C}_{19} \mathrm{H}_{27} \mathrm{~N}_{3} \mathrm{O}_{6}: 416.17921[\mathrm{M}+\mathrm{Na}]^{+}$; found: 416.17934. $[\alpha]_{\mathrm{D}}-81.9(c 0.15, \mathrm{MeOH})$ 


\section{Acknowledgements}

This work was supported by the FIRB program CHEMPROFARMANET (RBPR05NWWC), the Marie Curie ITN FP7 project CARMUSYS (PITN-GA-2008-213592) and Comune di Milano (Convenzione 55/2008). Exact mass were obtained from CIGA (Centro interdipartimentale grandi apparecchiature, Università degli Studi di Milano).

\section{References}

1 (a) J. Banchereau and R. M. Steinman, Nature, 1998, 392, 245-252; (b) D. N. J. Hart, Blood, 1997, 90, 3245-3287; (c) I. Mellman and R. M. Steinman, Cell, 2001, 106, 255-258.

2 (a) A. Cambi and C. G. Figdor, Curr. Opin. Immunol., 2005, 17, $345-$ 351; (b) E. McGreal, J. Miller and S. Gordon, Curr. Opin. Immunol., 2005, 17, 18-24; (c) C. Théry and S. Amigorena, Curr. Opin. Immunol., 2001, 13, 45-51.

3 C. G. Figdor, Y. van Kooyk and G. J. Adema, Nat. Rev. Immunol., 2002, $77-84$.

4 T. B. H. Geijtenbeek, R. Torensma, S. J. Van Vliet, G. C. F. van Duijnhoven, G. J. Adema, Y. van Kooyk and C. G. Figdor, Cell, 2000, 100, 575-585.

5 (a) G. Tabarani, M. Thepaut, D. Stroebel, C. Ebel, C. Vives, P. Vachette, D. Durand and F. Fieschi, J. Biol. Chem., 2009, 284, 21229-21240; (b) D. Serrano-Gomez, E. Sierra-Filardi, R. T. Martinez-Nunez, E. Caparros, R. Delgado, M. A. Munoz-Fernandez, M. A. Abad, J. Jiménez-Barbero, M. Leal and A. L. Corbi, J. Biol. Chem., 2008, 283, 3889-3903; (c) H. Feinberg, Y. Guo, D. A. Mitchell, K. Drickamer and W. I. Weis, J. Biol. Chem., 2005, 280, 1327-1335; (d) D. A. Mitchell, A. J. Fadden and K. Drickamer, J. Biol. Chem., 2001, 276, 28939 28945.

6 (a) T. B. H. Geijtenbeek, D. S. Kwon, R. Torensma, S. J. Van Vliet, G. C. F. Van Duijnhoven, J. Middel, I. L. M. H. A. Cornelissen, H. S. L. M. Nottet, V. N. Kewal Ramani, D. R. Littman, C. G. Figdor and Y. Van Kooyk, Cell, 2000, 100, 587-597; (b) P.-Y. Lozach, H. Lortat-Jacob, A. De Lacroix De Lavalette, I. Staropoli, S. Foung, A. Amara, C. Houles, F. Fieschi, O. Schwartz, J.-L. Virelizier, F. ArenzanaSeisdedos and R. Altmeyer, J. Biol. Chem., 2003, 278, 20358-20366; C. P. Alvarez, F. Lasala, J. Carrillo, O. Muniz, A. L. Corbi and R. Delgado, J. Virol., 2002, 76, 6841-6844.

7 (a) T. B. H. Geijtenbeek, S. J. van Vliet, E. A. Koppel, M. SanchezHernandez, C. Vandenbroucke-Grauls, B. Appelmelk and Y. van Kooyk, J. Exp. Med., 2003, 197, 7-17; (b) L. Tailleux, O. Schwartz, J. L. Herrmann, E. Pivert, M. Jackson, A. Amara, L. Legres, D. Dreher, L. P. Nicod, J. C. Gluckman, P. H. Lagrange, B. Gicquel and O. Neyrolles, J. Exp. Med., 2003, 197, 121-127.

8 (a) J. J. Reina, S. Sattin, D. Invernizzi, S. Mari, L. Martinez-Prats, G. Tabarani, F. Fieschi, R. Delgado, P. M. Nieto, J. Rojo and A. Bernardi, ChemMedChem, 2007, 2, 1030-1036; (b) D. A. Mitchell, N. A. Jones, S. J. Hunter, J. M. D. Cook, S. F. Jenkinson, M. R. Wormald, R. A. Dwek and G. W. J. Fleet, Tetrahedron: Asymmetry, 2007, 18, 15021510; (c) M. J. Borrok and L. L. Kiessling, J. Am. Chem. Soc., 2007, 129, 12780-12785; (d) F. Lasala, E. Arce, J. R. Otero, J. Rojo and R. Delgado, Antimicrob. Agents Chemother, 2003, 47, 3970-3972; (e) J. Rojo and R. Delgado, J. Antimicrob. Chemother., 2004, 54, 579-581; (f) G. Tabarani, J. J. Reina, C. Ebel, C. Vives, H. Lortat-Jacob, J. Rojo and F. Fieschi, FEBS Lett., 2006, 580, 2402-2408; (g) S.-K. Wang, P.-H. Liang, R. D. Astronomo, T.-L. Hsu, S.-L. Hsieh, D. R. Burton and C.-H. Wong, Proc. Natl. Acad. Sci. U. S. A., 2008, 105, 36903695; (h) O. Martinez-Avila, L. M. Bedoya, M. Marradi, C. Clavel, J. Alcami and S. Penades, ChemBioChem, 2009, 10, 1806-1809; (i) S. Sattin, A. Daghetti, Anna, M. Thepaut, A. Berzi, M. Sanchez-Navarro, G. Tabarani, J. Rojo, F. Fieschi, M. Clerici and A. Bernardi, ACS Chem. Biol., 2010, 5, 301-312; (j) O. Martinez-Avila, K. Hijazi, M. Marradi, C. Clavel, C. Campion, C. Kelly and S. Penades, Chem.-Eur. J., 2009, 15, 9874-9888; $(k)$ K. C. A. Garber, K. Wangkanont, E. E. Carlson and L. L. Kiessling, Chem. Commun., 2010, 46, 6747-6749.

9 E. J. Soilleux, Clin. Sci., 2003, 104, 437-446.

10 S. Pöhlmann, F. Baribaud and R. W. Doms, Trends Immunol., 2001, 22, 643-646.

11 (a) S. Pöhlmann, E. J. Soilleux, F. Baribaud, G. J. Leslie, L. S. Morris, J. Trowsdale, B. Lee, N. Cleman and R. W. Doms, Proc. Natl. Acad. Sci. U. S. A., 2001, 98, 2670-2675; (b) E. Van Liempt, C. M. C. Bank, P. Mehta, J. J. García-Vallejo, Z. S. Kawar, R. Geyer, R. A. Alvarez, R. D. Cummings, Y. van Kooyk and I. van Die, FEBS Lett., 2006, 580, 6123-6131; (c) E. Van Liempt, A. Imberty, C. M. C. Bank, S. J. Van Vliet, Y. Van Kooyk, T. B. H. Geijtenbeek and I. Van Die, J. Biol. Chem., 2004, 279, 33161-33167.

12 Y. Guo, H. Feinberg, E. Conroy, D. A. Mitchell, R. Alvarez, O. Blixt, M. E. Taylor, W. I. Weis and K. Drickamer, Nat. Struct. Mol. Biol., 2004, 11, 591-598.

13 H. Feinberg, M. E. Taylor, N. Razi, R. McBride, Y. A. Knirel, S. A. Graham, K. Drickamer and W. I. Weis, J. Mol. Biol., 2011, 405, 10271039.

14 G. Timpano, G. Tabarani, M. Anderluh, D. Invernizzi, F. Vasile, D. Potenza, P. M. Nieto, J. Rojo, F. Fieschi and A. Bernardi, ChemBioChem, 2008, 9, 1921-1930.

15 For a review on structural studies on the conformation of Lewis oligosaccharides see: E. Yuriev, W. Farrugia, A. M. Scott and P. A. Ramsland, Immunol. Cell Biol., 2005, 83, 709-717.

16 L. de Witte, A. Nabatov, M. Pion, D. Fluitsma, M. A. de Jong, T. de Gruijl, V. Piguet, Y. van Kooyk and T. B. H. Geijtenbeek, Nat. Med., 2007, 13, 367-371.

17 P. J. Goodford, J. Med. Chem., 1985, 28, 849-857.

18 H. Feinberg, D. A. Mitchell, K. Drickamer and W. I. Weis, Science, 2001, 294, 2163-2166.

19 H. Feinberg, R. Castelli, K. Drickamer, P. H. Seeberger and W. I. Weis, J. Biol. Chem., 2007, 282, 4202-4209.

20 Glide version 4.5, Schrödinger, LLC NY 2007.

21 W. C. Still, A. Tempczyk, R. C. Hawley and T. Hendrickson, J. Am. Chem. Soc., 1990, 112, 6127-6129.

22 A. L. Hopkins, C. R. Groom and A. Alex, Drug Discovery Today, 2004, 9, 430-431.

23 C. Guzzi, J. Angulo, F. Doro, J. J. Reina, M. Thépaut, F. Fieschi, A. Bernardi, J. Rojo and P. M. Nieto, submitted.

24 M. Andreini, M. Anderluh, A. Audfray, A. Bernardi and A. Imberty, Carbohydr. Res., 2010, 345, 1400-1407.

25 L. de Witte, A. Nabatov and T. B. H. Geijtenbeek, Trends Mol. Med., 2008, 14, 12-19.

26 M. A. W. P. de Jong, L. de Witte, M. Taylor and T. B. H. Geijtenbeek, J. Immunol., 2010, 185, 1633-1641.

27 M. Thépaut, J. Valladeau, A. Nurisso, R. Kahn, B. Arnou, C. Vives, S. Saeland, C. Ebel, C. Monnier, C. Dezutter-Dambuyant, A. Imberty and F. Fieschi, Biochemistry, 2009, 48, 2684-2698.

28 F. Halary, A. Amara, H. Lortat-Jacob, M. Messerie, T. Delaunay, C. Houlès, F. Fieschi, F. Arenzana-Seisdedos, J.-F Moreaus and J. Déchanet-Merville, Immunity, 2002, 17, 653-664.

29 MacroModel, version 9.5, Schrödinger, LLC, New York, NY, 2007.

30 W. L. Jorgensen, D. S. Maxwell and J. Tirado-Rives, J. Am. Chem. Soc., 1996, 118, 11225-11235. 